Modern Asian Studies 49, 6 (2015) pp. 1875-1902. (C) Cambridge University Press 2014 doi:10.1017/Soo26749X13000486 First published online 17 July 2014

\title{
Worshipping Relics and Animating Statues. Transformations of Buddhist statecraft in contemporary Laos*
}

\author{
PATRICE LADWIG \\ Max-Planck-Institute for Social Anthropology, Halle (Saale), Germany; and \\ Department of Social and Cultural Anthropology, University of Zurich, \\ Switzerland \\ Email:ladwig@eth.mpg.de
}

\begin{abstract}
In Laos—one of the few remaining 'officially' socialist countries-Buddhism was abolished as a state religion after the revolution in 1975. However, since the 1990 s the communist government has been increasingly using its patronage of Buddhism to gain legitimacy. With reference to the divine sources of power in Theravāda Buddhism, this article explores the extent to which modern Lao state socialism is still imbued with pre-revolutionary patterns of Buddhist kingship and statecraft. The analysis will focus especially on ritual patronage of a Buddhist relic shrine and on the recent inauguration of statues of deceased kings in the Lao capital, Vientiane. With reference to the ritual animation of 'opening the eyes' of the statues, and with regard to theories exploring the agency of objects, I argue that the Lao palladium has to be understood as being made up of 'living' entities. Finally, the article explores to what extent the control, worship, and creation of statues and relics today are still essential for the legitimacy of rule in the Lao People's Democratic Republic.
\end{abstract}

\section{Introduction}

Anthropology has produced an astonishing body of works dedicated to sacred kingship and forms of royal power. Studies of African

\footnotetext{
* Research on which this article is based was carried out in Vientiane and several provinces of Laos from 2003 to 2005 and during several visits between 2007 and 2012. Research was funded by the German Academic Exchange Service, the University of Cambridge, the University of Bristol, and recently by the Max-Planck-Institute for Social Anthropology. Thanks to the two anonymous reviewers for their valuable suggestions and work on the article. Also thanks to my numerous colleagues at the various institutions I have worked at over the years-they all helped me to think through the topics of this article. Finally, thanks to Michel Lorrillard and Yves Goudineau and all others at the École Française d'Extrême-Orient in Vientiane for hosting me during my multiple stays in Laos in the last few years.
} 
political systems, of Buddhist kingship in Southeast Asia or larger comparative examinations have received much attention. ${ }^{1}$ Looking at the contemporary discourses in political anthropology, Thomas Hansen and Finn Stepputat complain that anthropological explorations of sacred kingship have barely succeeded in crossing the line of the post-colonial. The formation of modern nation-states is often analysed using a different body of theories, employing notions such as governmentality and looking at the more dispersed effects of power in the body politic. ${ }^{2}$ The analysis of the 'traditional' world of royal power and sacred kingship rarely features in the political anthropology of the 'modern' nation-state. However, among the numerous anthropological, historical, and Buddhological studies on the interaction of politics and religion in Theravāda Buddhist kingship in mainland Southeast Asia and Sri Lanka, there are a few examples where this transposition to the modern nation-state has been researched. ${ }^{3}$ The fact that there are no longer Buddhist kings in some of these countries (Laos, Burma, Sri Lanka, for example) has been explored mainly in terms of absence or lack. But what about the enduring significance of models of kingship and Buddhist statecraft in modern nation-states, despite their disappearance? Jonathan Spencer, for example, claims that indigenous ideas about kingship have continued to animate the political imagination in Sri Lanka, but without any kings to do the animating since the early nineteenth century'.

This article explores the question of the extent to which ideas about Buddhist kingship and statecraft are still relevant in Laos, one of the

\footnotetext{
${ }^{1}$ For African kingship, see the classical volume by E. Evans-Pritchard and M. Fortes (eds), African political systems, Oxford University Press, London, 1940. For Southeast Asia, see, for example, S. Tambiah, World conqueror and world renouncer. A study of Buddhism and polity in Thailand against a historical background, Cambridge University Press, Cambridge, 1976. Hocart's work explores kingship from a global, comparative perspective. See A. Hocart, Kings and councillors. An essay in the comparative anatomy of human society, University of Chicago Press, Chicago, 1970.

${ }^{2}$ T. Hansen and F. Stepputat, 'Sovereignty revisited', Annual Review of Anthropology, Vol. 35/2, 2007, pp. 299-300.

${ }^{3}$ For Sri Lanka see, for example, B. Kapferer, Legends of people, myths of state, Smithsonian Institution Press, Washington, 1998. For South Asia, see R. Burghart, The condition of listening. Essays on religion, history and politics in South Asia, Oxford University Press, New York, 1990. For Burma and the role of Buddhism in Burmese socialism in the early post-colonial period, see E. Sarkisyanz, Buddhist backgrounds of the Burmese revolution, Martinus Nijhoff, The Hague, 1965.

${ }^{4} \mathrm{~J}$. Spencer, 'Post-colonialism and the political imagination', The Journal of the Royal Anthropological Institute, Vol. 3/1, 1997, p. 9.
} 
few remaining socialist countries. ${ }^{5}$ Although Buddhist kingship has all but disappeared in Laos since the communist revolution in 1975 and Buddhism is no longer the state religion, current cultural politics in Lao is involved in a process of 're-Buddhification'. ${ }^{6}$ I argue that modern Lao state socialism is still imbued (and increasingly so) with patterns of Buddhist statecraft. Taking a comparative perspective grounded in Buddhist studies and anthropology, I specifically want to investigate the Buddhist sources of power and authority embodied in relic shrines and statues. I will first discuss the general link between relics, statues, and statecraft in Theravāda Buddhism. The next section will explore the implications of the worship of relics and the associated rituals in my fieldsite in the capital Vientiane. Here, the worship of the 'national' Lao stūpa $a^{7}$ - the That Luang (great stüpa) - reveals that relics have to be understood as 'animated' and 'living entities'. ${ }^{8}$ In the following section I will discuss the ritual animation and inauguration of two statues of Lao Buddhist kings of the past in 2003 and 2010. I argue that the enduring significance of Buddhist statecraft is grounded in the qualities, materiality, and effects of the objects that constitute the Lao palladium. ${ }^{9}$ The control, worship, and creation of relics and statues are therefore explored with reference to recent literature on the agency of objects which tries to move beyond seeing them

\footnotetext{
${ }^{5}$ Laos is ethnically very heterogeneous. My observations are valid largely only for the ethnic Lao in the Vientiane region. Non-Buddhist ethnic minorities (comprising about 40 per cent of the population) who have not been socialized in a Buddhist context often do not hold such beliefs in relics and statues. However, the increasing return to Buddhism is spread via the media in Laos and also through state institutions such as schools.

${ }^{6}$ G. Evans, The politics of ritual and remembrance. Laos since 1975, Hawai'i University Press, Honolulu, 1998, p. 67.

${ }^{7}$ The language is indicated in brackets with Pāli or Sanskrit. Terms in Lao are given in brackets without signifying the language. There is no official and widely recognized system of transcription for Lao. Most terms, however, should be easily recognizable.

${ }^{8}$ Stüpa (Sanskrit; Pāli: thüpa) originally referred to a grave hill (or 'heap'), but then began to be used throughout the Buddhist world to refer to monuments that house the relics of the Buddha or of other holy figures. The Lao that (as in That Luang) derives from Pāli dhätu (element, core) and also connotes 'relic'. Also widespread in Laos and Thailand is the term chedi, from Pāli cetiya (reminders, memorials) that, in relation to the classifications of relics, is understood as a piece of the body of the Buddha (Sankrit: śariraka). For the ritual uses of cetiya in some Lao rites, see L. Gabaude, Les cetiya de sable au Laos et en Thailande, EFEO, Paris, 1979. For further connotations and words relating to relics, see the next section of this article.

${ }^{9}$ Palladium originally signifies a statue of Athena in Troy which safeguarded the city. I employ it here to refer to Buddhist statues and relics that are believed to provide protection, safety, fertility, and prosperity.
} 
solely as representations or symbols of power. I conclude that the rituals associated with the worship of relics, and the circumstances of the creation of sacred statues have changed, but that the specific religious imaginary attached to them-despite transformations and discontinuities—is still efficacious.

\section{Relics, statues, and statecraft in Theravāda Buddhism}

There have been numerous examinations of the interaction of Buddhism, kingship, and political order, specifically regarding Southeast Asian Theravāda Buddhism. ${ }^{10}$ Some of these studies have investigated the religious underpinnings of contemporary politics in mainland Southeast Asia and have shown that, despite the secular constitutions of these states, the distinction between the secular and the religious is often blurred. ${ }^{11}$ Historically speaking, Buddhism and Hinduism brought a process of Indianization to mainland Southeast Asia which has been crucial for the formation of larger political entities. Buddhism as a world religion fuelled a process of political centralization, brought script, a class of religious professionals, and new systems of supralocal training and instruction. Through the adoption of Pāli and Sanskrit as languages, Buddhism, its literary works, and its technical-ritual treatises connected people to larger

${ }^{10}$ Oft-cited studies in this field in Thailand are Tambiah, World conqueror; and Y. Ishi, Sangha, state and society. Thai Buddhism in history, Hawai'i University Press, Honolulu, 1996; and M. Mendelson, Sangha and state in Burma. A study of monastic sectarianism and leadership, Cornell University Press, Ithaca, 1975. Two recent volumes attest to the continuing relevance of the topic in modern nation-states. See I. Harris (ed.), Buddhism, power and political order, Routledge, London, 2008; and B. Brac de la Perrière and M. Reiniche (eds), Les apparences du monde: Royautés hindoues et bouddhiques de l'Asie du Sud et du Sud-Est, École Française d'Extrême-Orient, Paris, 2007. For the latest work on Laos, see J. Holt, Spirits of the place. Buddhism and Lao religious culture, University of Hawai'i Press, Honolulu, p. 76 ff.

${ }^{11}$ Ian Harris's excellent article on the boundaries of the Cambodian nation-state, for example, starts by employing Carl Schmitt's dictum that 'All significant concepts of the modern theory of the state are secularized theological concepts.' He sees parallels between Buddhist concepts of sima $\bar{a}$ (originally marking a territory of a temple) and the current national boundaries of Cambodia. I. Harris, 'Rethinking Cambodian political discourse on territory: genealogy of the Buddhist ritual boundary $(\operatorname{sim} \bar{a})$ ', Journal of Southeast Asian Studies, Vol. 41/2, 2010, p. 215. For a more general and recent overview on the now widely and critically discussed distinction between the secular and the religious, and the secularization thesis in general, see, for example, F. Cannell, 'The anthropology of secularism', Annual Review of Anthropology, Vol. 39/1, 2010 , pp. $85^{-100 .}$ 
cultural and political entities, and also contributed to the rise of a rich vernacular literature. ${ }^{12}$

For centuries the construction of temples, relic shrines, and statues have been strategies for mapping Buddhist kingdoms through a sacred topography, exemplifying a king's power and adherence to Buddhism. The ideological blueprint for Buddhist statecraft is the Mauryan king Aśoka, who ruled over large parts of India around $25^{\circ}$ BC. Aśoka is said to have fervently promoted Buddhism and is also mentioned in numerous Lao and Thai chronicles associated with Buddhist relics. Sometimes their mytho-historical origin is traced back to Sri Lanka and Aśoka. In this model of statecraft the ruler was considered to be a 'wheel-turning-king' (Pāli: cakkavatti) standing at the apex of social organization. He granted the monastic order (Pāli: sangha) protection and supported it, while the saingha, through spreading the dhamma (teaching of the Buddha, doctrine, truth), gave the leader legitimacy for his rule. The early Lao kingdoms display the first clear signs of the Buddhification of royal power around the mid-fifteenth century when kings began to be labelled cakkavatti. ${ }^{13}$ Projecting this generalized and timeless view of Buddhist political organization to Laos and mainland Southeast Asia is by no means unproblematic. As demonstrated for fourteenth to sixteenth century northern Thailand, the cakkavattiideal could take on multiple forms in mediating between the realm of religion (Sankrit: sāsanacakra) and politics (Sanskrit: ānācakra). ${ }^{14}$ Moreover, the power of some of the kingdoms of mainland Southeast Asia was limited to river basins and the lowlands, with only marginal integration with the non-Buddhist populations in the hills. ${ }^{15}$ Buddhist

\footnotetext{
${ }^{12}$ For the Indianization of mainland Southeast Asia, see G. Coedès, The Indianized states of Southeast Asia, Hawai'i University Press, Honolulu, 1968. Although Buddhism's influence was crucial to increased political centralization, this process was still very fragmentary. See V. Liebermann, Strange parallels: Southeast Asia in global context.c. $800-$ I830, Volume I: Integration on the mainland, Cambridge University Press, Cambridge, 2003 , p. 58 , for an overview.

${ }^{13}$ See M. Lorillard, 'Lao history revisited: Paradoxes and problems in current research', South East Asia Research, Vol. 14/3, 2006, p. 401.

${ }^{14}$ See the excellent chapter by D. Swearer and S. Premchit, 'The relationship between the religious and political orders in northern Thailand (14th-16th centuries)', in B. Smith (ed.), Religion and legitimation of power in Thailand, Laos and Burma, Anima Books, Chambersburg, 1978, pp. 20-33.

${ }^{15}$ See Liebermann, Strange parallels, pp. $36-41$, for the limited, but still significant, cultural integration though Buddhism in mainland Southeast Asia. Until today, Laos remains the country with the lowest population quota (about 6o per cent) of Buddhists in mainland Southeast Asia. Historical research has shown that the expansion of Lao kingdoms was mainly limited to the valleys of the Mekong and other rivers, and hardly
} 
concepts of rule and statecraft were heavily localized and often far away from what were presented as an ideal in chronicles (phongsavadan) and local histories (tamnan). ${ }^{16}$ What previous research on the political and social organization often has described as large mandalas misses out on the localization of these models. Early polities in the region of Laos and Thailand that assimilated Buddhism were based on the organization of mueang (principality) and the term mandala hardly turns up in any of the sources. ${ }^{17}$

However, what unifies these localizations of Buddhist statecraft is the significance of powerful palladia. Right from the beginning Buddhist concepts of statecraft and rule were linked to the possession and ritual patronage of relics and powerful statues. With the waxing and waning of kingdoms, and quarrels about succession, relics and statues were considered crucial signifiers of the power of the centre. In Lao and Thai history, 'the possession of certain Buddha statues and relics, rather than kinship, was interpreted as conferring legitimacy and power to kings and rulers, because these statues were treated as

ever reached into the mountains. See M. Lorrillard, 'Pour une géographie historique du bouddhisme au Laos' in Y. Goudineau and M. Lorrillard (eds), Recherches nouvelles sur le Laos, École Française d'Extrême-Orient, Bangkok, 2008, pp. 113-181.

${ }^{16}$ Some researchers suggest, with reference to Thailand, that the picture presented above is much more complicated and involves a multitude of actors from different religious traditions. See P. Skilling, 'King, sangha, and Brahmans: ideology, ritual, and power in pre-modern Siam' in I. Harris (ed.), Buddhism, power and political order, Routledge, London, 2008. Moreover, there are also subtle distinctions between the king as cakkavatti (universal monarch), dhammarāja (righteous ruler), and even devarāja (god-king). For the textual backgrounds of these conceptions as depicted, for example, in the Cakkavatti Sīhanāda-Sutta, see S. Collins, Nirvana and other Buddhist felicities. Utopias of the Pali imaginaire, Cambridge University Press, Cambridge, 1998, p. $414 \mathrm{ff}$. and especially pp. 480-496. More important, however, than these discussions in my opinion is the localizations of political concepts in Laos beyond general references to Buddhist kingship. See F. Reynolds, 'Ritual and social hierarchy: an aspect of traditional religion in Buddhist Laos', History of Religions, Vol. 9/1, 1969, pp. 81-101; C. Archaimbault, Structures religieuses lao (rites et mythes), Vithagna, Vientiane, 1973, pp. $77-97$.

${ }^{7}$ Tambiah, taking his inspiration from Wolters, understands mandala (Sanskrit for 'circle') as a 'galactic polity'. See S. Tambiah, 'The galactic polity: the structure of traditional kingdoms in Southeast Asia', Annals of the New York Academy of Sciences, Vol. 293, 1977, pp. 69-97; and O.W. Wolters, History, culture and region in Southeast Asian perspectives, Institute of Southeast Asian Studies, Singapore, 1999, p. $126 f$. Although a useful concept, the term mandala hardly ever features in Lao chronicles and instead, localized and pre-Buddhist concepts of political and social organization such as baanmueang ('village-principality') are invoked. See J. Raendchen, 'The socio-political and administrative organisation of müang in the light of Lao historical manuscripts', Paper presented at the conference 'The Literary Heritage of Laos', Vientiane, 2004. 
the palladia of their kingdoms and principalities'. ${ }^{18}$ Again recalling the figure of King Aśoka, relics in this sense were of prime importance for establishing authority, marking the Buddhicization of a territory and its population. The figure of the king was linked to a cosmology of relics, statues, and other objects. The Aśokāvadanna (the legend of Aśoka) had 'the greatest influence on the development of Buddhist traditions concerning the ideal of the wheel-turning king (cakravartin) and his relationship with relics'. ${ }^{19}$ For Anne Blackburn, 'the protection, enhancement, and deployment of relics constituted a core technology of state' in South and Southeast Asia. ${ }^{20}$ Hence, in the historiography of the region, the reigns of kings and that of statues and relics are often bound to each other. Many chronicles from the pre-modern history of the region focus on relics and statues, their travels, and their establishment in shrines and temples in royal capitals through donations given by kings, thereby creating a 'Buddha-land' (Pāli: buddha-desa), as, for example, documented for northern Thailand. ${ }^{21}$ From this perspective, then, it is not only the figure of the king itself, but also the material manifestations of kingship that seem to be of great importance.

The statues and relics installed in the centre of these kingdoms had a crucial role in legitimizing rule. They were housed in large palaces and representative buildings, and were the object of ritual worship that was believed to be of crucial importance for the fate of the kingdom. These cosmological interpretations of statecraft put forward, for example, by Robert Heine-Geldern have also been taken up by Benedict Anderson. In a now classic article on Javanese conceptions of power, Anderson suggested that power radiates from the centre of a kingdom. Although

${ }^{18} \mathrm{~S}$. Tambiah, 'Famous Buddha images and the legitimation of kings: the case of the Sinhala Buddha (Phra Singh) in Thailand', Res, Vol. 4, 1982, p. 5 .

${ }^{19}$ B. Ruppert, 'Relics and relic cults' in Robert Buswell (ed.), Macmillan Encyclopedia of Buddhism, Macmillan Reference, New York, 2005, p. 71 7. For a complete translation of the Sanskrit text, see J. Strong, The legend of king Aśoka. A study and translation of the Aśokāvadāna, Princeton University Press, Princeton, 1984.

${ }^{20}$ A. Blackburn. 'Buddha-relics in the lives of South Asian polities', Numen, Vol. 57/3-4, 2010, p. 319.

${ }^{21}$ For an excellent overview of the local literature and some chronicles on relics and statues in a neighbouring region, see F. Lagirarde, 'Temps et lieux d'histoires bouddhiques: à propos de quelques chroniques inédites du Lanna', Bulletin de l'Ecole Francaise d'Extreme-Orient, Vol. 94, 2007, pp. 59-94. Research on northern Thailand and the role of relics and statues in 'Buddhicizing' the landscape has been most extensive in this regard. See D. Swearer, 'Signs of the Buddha in northern Thai chronicles', in D. Germano and K. Trainor (eds), Embodying dharma. Buddhist relic veneration in Asia, State University of New York Press, Albany, 2004, pp. 145-162. 
these accounts have been rightly criticized for overemphasizing the role of the centre, ${ }^{22}$ I believe that their focus on the material aspects of local conceptions of power can still be useful. Relics and statues can also be understood as receptacles of and distribution points for this kind of power. While the scattered kingdoms of pre-colonial Laos were marked by insecure rules regarding the passing on of positions of power, the materializations of power in statues and relics played in important role in stabilizing these systems. According to Stanley Tambiah, in pre-colonial mainland Southeast Asia it is therefore also 'the possession of palladia and regalia that are enduring sedimentations or objectifications of power and virtue. Possession of them is a guarantee of legitimacy, and these embodiments of virtue and power will remain with the possessor for as long as he is deserving. ${ }^{23}$ Even with the vanishing of the Buddhist king, the material manifestations of rule and legitimacy, and the cosmologies behind them, can remain efficacious. This, for example, has been attested to in Sri Lanka. Here, the rites for the sacred tooth relic in Kandy have been carried out without a king for over 100 years, but the understandings of worshippers in relation to the powers of the relic have remained remarkably stable and continue to influence politics. ${ }^{24}$ In the following section I will discuss this continuity with reference to the most important Buddhist relic in Laos and its association with prosperity and fertility.

\section{Worshipping relics in contemporary Laos}

Laos is one of the few remaining socialist countries and officially endorses a secular political line. When the Pathet Lao took power in 1975, there was a short, hardline period, marked by the abolishment of Buddhism as a state religion, severe restrictions on all kinds of religious festivals, constant curfews, and paranoia-style politics

\footnotetext{
${ }^{22}$ B. Anderson, 'The idea of power in Javanese culture' in C. Holt (ed.), Culture and politics in Indonesia, Cornell University Press, Ithaca, 1972, pp. 1-70. For an overview of the critiques of this cosmological model, see K. R. Hall, A history of early Southeast Asia: maritime trade and societal development, Lexington Press, Littlefield, 2011 , p. $14 \mathrm{ff}$.

${ }^{23}$ Tambiah, 'Famous Buddha images', p. 18.

${ }^{24}$ For this continuity, see H. L. Seneviratne, Rituals of the Kandyan state, Cambridge University Press, Cambridge, 1978, p. $167 \mathrm{ff}$.
} 
due to the instability of the regime. ${ }^{25}$ The phase in which the ruling party tried to put its early ideas of socialism into practice, however, lasted only for a brief time. After just ten years of trying to embed state socialism, the first reforms were introduced in 1986 . The 1990 s saw a revitalization of Buddhism, with state rituals becoming more pompous, attended by Communist Party cadres. The Lao People's Revolutionary Party has been involved in a delicately orchestrated revitalization of Buddhism. ${ }^{26}$ With Buddhist institutions firmly integrated into the Party state, Buddhism, and the language, moral values, and lifestyles associated with it, are now again promoted. The Buddhification of everyday culture and the political is observable, at least in regions with a high proportion of ethnic lowland Lao. Although socialist discourses on religion being a 'waste of resources' are sometimes still invoked by hardliners, since the 1990 s the Communist Party has been relying increasingly on its patronage of Buddhism. Lao state ritualism especially exemplifies the partial continuity between 'worldly' rule in a communist one-party state and Buddhist conceptions of statecraft linked to relics and statues.

The ritual for the Buddha's relic in Vientiane is perhaps the prime example of this new policy. In the period of reformed socialism, the That Luang 'has become the central symbol through which the nation remembers itself'. ${ }^{27}$ Its icon now features prominently on everything from tourist brochures to Lao banknotes and reflects the ideological changes that have occurred in the reform phase. ${ }^{28}$ The yearly boun that luang (festival of the great stüpa) in the capital Vientiane is the most important state ritual in contemporary Laos. Lasting for over a week, the ritual aims at the veneration of the Buddha's relic supposedly enshrined in the That Luang. It has become a display of the patronage

${ }^{25}$ For an overview of this phase of Lao history, see M. Stuart-Fox, A history of Laos, Cambridge University Press, Cambridge, p. $168 \mathrm{ff} . ;$ G. Evans, A short history of Laos. The land in-between, Allen and Unwin, Crow's Nest, 2003, p. 15 off.

${ }^{26}$ One has to remark that the revitalization of Buddhism outlined above happens under the relatively strict and successful surveillance of the state. For the genealogy of this relationship, see P. Ladwig, 'Prediger der Revolution: Der buddhistische Klerus und seine Verbindungen zur Kommunistischen Bewegung in Laos (1957-1975)', Jahrbuch für Historische Kommunismusforschung, Vol. 15, 2009, pp. 181-197. For the contemporary position of Buddhism, see V. Pholsena, Post-war Laos. The politics of culture, history and identity, Cornell University Press, New York, 2006, p. 70.

${ }^{27}$ Evans, The politics of ritual and remembrance, p. 41 .

${ }^{28}$ For an overview of the iconographic changes under reformed socialism, see O. Tappe, 'A new banknote in the people's republic. The iconography of the Kip as a representation of ideological transformations in Laos (1957-2006)', Internationales Asienforum, Vol. 38/1-2, 2007, pp. 87-108. 
power of the Lao Communist Party and, to my knowledge (gained from oral histories from my fieldsite in Vientiane), the ritual was never discontinued, even during the early hardline phase of the new regime of the Lao People's Revolutionary Party.

For centuries the That Luang located in Laos's capital Vientiane has assumed the role of a palladium of various kingdoms, and does so in the contemporary period for the Lao nation-state. Even under high socialism, the government retained its centrality in the urban and architectural landscape of Vientiane: the new National Assembly and other socialist buildings were adjusted to the spatial axis formed by the relic shrine where socialist parades took place. ${ }^{29}$ The monument is recorded in chronicles and epigraphic sources labelled lokaculami stüpa, which signifies the 'stüpa of the diadem' ${ }^{30}$ King Setthathirath (15341572 ) is said to have sponsored a rebuilding of the stuppa in $15^{66}$ to mark the movement of the capital from Luang Phabang to Vientiane. Marc Askew states that this construction 'was Xethatirath's supreme act of claiming his legitimacy as a universal monarch (Chakkapat) in an Indic tradition'. ${ }^{31}$ Although epigraphic sources recently analysed by Michel Lorrillard describe it as jinaguyhadhātu (a hidden or secret relic), it is widely believed to be a relic of the Buddha himself. ${ }^{32}$ Moreover, the mythical history of the relic-which travelled from Sri Lanka to the Lao kingdom-builds a bridge to King Aśoka himself. ${ }^{33}$

What is the significance of relics and how are they-in Buddhism in general and in localized conceptions-understood? In Theravāda Buddhism, relics are believed to be living beings that emanate power,

${ }^{29}$ For the socialist period, see C. Long, 'The Pathet Lao capital', in M. Askew, W. Logan and C. Long (eds), Vientiane. Transformations of a Lao landscape, Routledge, London, 2007 , p. 156 . For the continuity of the sacred spatial layout around the That Luang and the construction of revolutionary monuments in the traditional style, see R. Martinez, 'Remembering within a sacred space in Vientiane', The Journal of Lao Studies, Vol. 2/2, 2011 , pp. 75-103.

${ }^{30}$ See M. Lorrillard, 'Les inscriptions du That Luang de Vientiane: données nouvelles sur l'histoire d'un stupa lao', Bulletin de l'Ecole Francaise d'Extreme-Orient, Vol. 90-91, 2003-04, pp. 317-318.

${ }^{31}$ M. Askew, 'From glory to ruins', in Marc Askew, William Logan and Colin Long (eds), Vientiane. Transformations of a Lao landscape, London, Routledge, 2007, p. 52.

${ }^{32}$ Lorrillard, 'Les inscriptions', pp. 316-317.

${ }^{33}$ See P. Ladwig, 'Relics, "representation" and power. Some remarks on stupas containing relics of the Buddha in Laos', Tai Culture, Vol. 5/1, 2000, pp. 70-84. For a wider contextualization of the link between Aśoka, relics, and political centralization, see the excellent study by J. Strong, The relics of the Buddha, Princeton University Press, Princeton, 2004, p. $124 \mathrm{ff}$. 
that reactualize the presence of the Buddha. Research on early Indian Buddhism has shown that relics were understood as living beings that have legal rights, possess things, and can influence not only the subjectivity of worshippers, but also the fate of a whole kingdom. ${ }^{34}$ They not only represent the absent Buddha or his teachings, but are also active entities. Despite all transformations through time, these notions have remained remarkably stable in the Theravāda world. ${ }^{35}$ In Thai and Lao cosmology, relics are said to display the 'six-coloured Buddha rays' stemming from the enlightenment of the Buddha. ${ }^{36}$ There are multiple conceptions of the power inherent in relics and statues: some sources and informants describe them as saksit, which suggests some resemblances to Anderson's description of power in Javanese culture. ${ }^{37}$ In a more localized conception, beyond the Theravāda focus, the relic in the That Luang is understood as the ming-khwan of Laos and the kingdoms of the past. Khwan is a preBuddhist concept denoting soul (albeit a living being) and ming is a Chinese expression for life or fate ${ }^{38}$ The relic's worship and its fate are deemed essential for the prosperity and fortune of the country. ${ }^{39}$

${ }^{34}$ For the living qualities of relics in early Indian Buddhism, see G. Schopen, 'Burial ad sanctos and the physical presence of the Buddha in early Indian Buddhism. A study in the archaeology of religions', Religion, Vol. 17/3, 1987, pp. 193-225. For a theoretically informed and comparative study of Buddhist relics through time, see the introduction to the excellent volume by Germano and Trainor (eds), Embodying dharma, pp. 1-27.

${ }^{35}$ For relics that bring the Buddha and the dhamma to life again and thereby reactualize the Sri Lankan Theravāda Buddhist tradition, see K. Trainor, Relics, ritual, and representation in Buddhism. Rematerializing the Sri Lankan Theravāda tradition, Cambridge University Press, Cambridge, 1997. Although Sri Lanka is obviously a different case from Laos, I think that a comparison that is limited to Theravanda Buddhism (which in itself is already quite heterogeneous) allows for the discovery of certain shared features in Buddhist conceptions of relics.

${ }^{36}$ C. Archaimbault and G. Coedès, Les trois mondes (Traibhûmi Brah Rvan), École Française d'Extrême-Orient, Paris, 1973, p. 184 .

${ }^{37}$ According to Anderson, "power in traditional Javanese political thought is seen as an intangible, mysterious, and divine energy that animates the universe' ('The idea of power', p. 7). Power is also a force that cannot be simply destroyed or created, but can be accumulated in the centre and then flow to the periphery. Relics and statues in Thai and Lao conceptions, described as saksit, derive from Sanskrit shakti (strength, source of empowerment) and sitthi (denoting supernatural powers). The term is often simply translated as 'holy', but it has the characteristics of an energy that can be stored or distributed.

${ }^{38}$ For the concept of ming, see M. Granet, La pensée chinoise, Editions Albin Michel, Paris, 1968, p. 376 .

${ }^{39}$ For an account of the pre-revolutionary beliefs in the powers of the That Luang relic, see M. Zago, Rites et cérémonies en milieu bouddhiste lao, Universita Gregoriana, Rome, 1972 , p. 328 . 
As living beings, however, relics also have to be ritually entertained in order to cause prosperity and good fortune. In the culturally close region of northern Thailand, 'worshipping the Buddha's relics was a way to renovate their power, and consequently, the power of the king, kingdom and its people'. ${ }^{40}$ This association of relics with fertility, prosperity, fortune, and rule is a Theravāda-wide pattern, exemplified, for example, by the Sri Lankan Tooth relic. John Strong states that the 'possession of the Buddha's tooth was seen as an indispensable attribute of kingship. Its cult was the privilege and duty of the legitimate ruler and was thought to ensure social harmony, regular rainfall, bountiful crops, and righteous rule. Its possession meant power. ${ }^{41}$

However, practice of the complex rites surrounding worship has been carefully re-engineered since $\mathbf{1 9 7 5}$. Each year, monks from the monastery in my fieldsite in Vientiane were provided with detailed organizational plans drawn up by the state authorities. The festival is also an occasion to meet up with relatives who come from all over the country. Thousands of monks also come from the provinces and participate in the ritual. The role formerly filled by the Buddhist king $^{42}$ has been taken over by delegates from the Communist Party and the president. When I observed the ritual in 2005 it was President Bounyang Vorachith who opened the ritual offering cycle. The temple in which I carried out my fieldwork from 2003-2005 is located close to the That Luang. In interviews during and after the festival it emerged that older laypeople were critically aware of the fact that the king was no longer present at the ritual. Whereas young people just knew this from hearsay, the elders also noted some discontinuities with the performances before the revolution in $1975 \cdot{ }^{43}$ However, this

${ }^{40}$ S. Premchit and D. Amphay, The Lan Na twelve months traditions, Chiang Mai University Press, Chiang Mai, 1992, p. 128.

${ }^{41} \mathrm{~J}$. Strong 'Relics' in M. Eliade (ed.), Encyclopedia of religion, Macmillan, New York, 1987 , Vol. 12 , p. 280.

${ }^{42}$ The last king of Laos was Savang Vatthana (1907-1984?) who resided in Luang Prabang, north of Laos. After the communist takeover, the Pathet Lao sent him and other members of his family to a 're-education camp' from where he never returned. Revolutionary leader and long-term president of Laos Kaysone Phomvihane admitted during a visit to France that the king passed away in 1984 at the age of 77 . See G. Evans, The last century of Lao royalty. A documentary history, Silkworm Books, Chiang Mai, 2009, for further details on the Lao royal family and its fate.

${ }^{43}$ These were primarily related to the absence of symbols of royalty, the committee character of the organization, and the 'commercialization' of the rites at the cost of religious serenity. There is unfortunately no space here to look at the ethnography 
did not necessarily diminish the ritual efficacy of the rite. Having already internalized the role of the monument in the modern national imaginary, most stated that the That Luang is a symbol (sanyalak) of contemporary Laos. However, when probing in more detail or making the relic a topic of the conversation, many locals from Vientiane mentioned that its worship is crucial for the prosperity (caloen) and development (pathana) of the country. Well-educated Buddhists directly linked the That Luang to the story of King Aśoka, and his striving to spread Buddhism and the teachings of the Buddha. For them, the stüpa signified the coming and the presence of Buddhism and his teachings (dhamma) in Laos. One monk, when asked about the role of the stüpa and relics, elaborated on this:

Relics have from the beginning been very important for the spread of the dhamma. Although the Buddha has gone to nirvana, his relics are still here and spread his teaching. The relic in the That Luang is said to have come to Laos with King Aśoka and is saksit. When the relic is worshipped, this brings prosperity and harmony to the nation.

Let us dissect some of the features attributed to the relic and the That Luang. Caloen is a general term for prosperity and today it is often used to describe the general economic state of affairs. It is also used at the end of most Buddhist rituals when a wish is expressed that the rite might give the worshippers health and prosperity (khwamsuk lae khwamcaloen). Pathana derives from Pāli vaddhana and is understood in the sense of expansion, enlargement, growth, and fostering. ${ }^{44}$ Monks often described their personal development, based on keeping moral precepts or meditation, with the term pathana, but today it also has a larger semantic field beyond spiritual development, namely 'development' in general. Indeed one hears the term so often that it has almost become synonymous with the meaning of modernization. When I asked the monk quoted above what caloen and harmony meant for him in this context, he referred to the development of people's minds (pathana cit) through the dhamma, but also to economic growth, which would then bring harmony to society as a whole.

of the rite in detail, but for the discontinuities and contradictions caused through the absence of the king, see G. Evans, 'Revolution and royal style: Problems of postsocialist legitimacy in Laos' in C. Shore and S. Nugent (eds), Elite cultures: anthropological perspectives, Routledge, London, 2002, pp. 189-207.

${ }^{44}$ For the semantic field of vaddhana, see T. Rhys-Davids and W. Stede, Pāli-English dictionary, Minisharam Publishers, Dehli, 2001, p. 595 . 
Thus, besides having strong Buddhist underpinnings, reflected in ritual language and sermons in monasteries, caloen and pathana are terms that are very present in Lao public discourses about modernization and economic development. Interestingly, these days the festival also includes a large trade fair, in which Laos's economic achievements are presented. The stalls are grouped around the That Luang on a large esplanade and is a good example of how prosperity and fertility, traditionally linked to wet-rice cultivation and rainfall, are thereby transposed into the modern period of market capitalism, economic innovation, and progress. But with large parts of Laos still a rural peasant society, the agricultural and fertility symbolism has not yet disappeared. The ritual also draws large crowds from the provinces and for me it was remarkable that people from my second fieldsite in Khammouan province (all engaged as peasants in wet-rice cultivation) made direct links between agricultural fertility and the worship of the relic. One of them stated: 'When the leaders of the nation (pathan pathet) perform the ritual accordingly, then there will be abounded fish in the ponds and rice in the fields.' Pathan pathet is a term that entered Laos only in 1975 after the revolution. The latter part of the sentence-relating to the abundance of resourcesI have heard very often in both Laos and Thailand. It is an almost verbatim quote from the Ramkham Haeng inscription from 1 292: 'In the time of King Ramkhamhaeng this land of Sukhothai is thriving. There are fish in the water and rice in the fields'. It is widely used in Thai nationalist discourse and has made its way to Laos. ${ }^{45}$ This also alludes to the influence of Thailand in today's Laos. Most Lao watch Thai television, or travel to Thailand. Given both countries' common history regarding Theravāda Buddhism and the similarities in language and cultural meanings attached to concepts such as caloen and pathana, this hardly comes as a surprise and points to similar imaginaries regarding Buddhism, fertility, and prosperity. The present Thai king and King Chulalongkorn (1868-1910) are also described as developers and modernizers, thereby fusing ideas about Buddhist kingship with modernity, development, and prosperity. ${ }^{46}$

${ }^{45}$ The authenticity of this inscription has been heavily contested. See D. Wyatt, Thailand. A short history, Yale University Press, New Haven, 1984, p. $54 \mathrm{ff}$.

${ }^{46}$ For the cult of the present Thai king and that of Chulalongkorn, see I. Strengs, Worshipping the great moderniser: King Chulalongkorn, patron saint of the Thai middle class, NUS Press, Singapore, 2009. Although there have been significant adaptations of these modern forms of kingship, there are nevertheless also crucial continuities to be found. For King Mongkut (1805-1868), the alleged 'science and technology modernizer' of 
The description above of Buddhist relics and their effects as an essential part of the palladium of Buddhist kingdoms, or modern Buddhist nation-states, is also applicable to certain Buddha statues. The second most important palladium in Laos is the Phabang, today located in Luang Phabang in north Laos, the seat of the last king of Laos. It is an $83 \mathrm{~cm}$ high Buddha image made from gold, silver, and bronze and is said to have come to Laos from Cambodia in the fourteenth century. Its earlier origins are supposed to have been in Sri Lanka and its move to Luang Phabang was said to have been accompanied by the arrival of Buddhist monks and scriptures, which signifies the 'true' coming of Buddhism to the area. ${ }^{47}$ Like the relic enshrined in the That Luang, the Phabang features in many Lao and Thai chronicles and its possession reflects the changing power constellation in the region. It was removed to Bangkok several times when the Siamese dominated the region, but was finally given back to Laos by King Mongkut in $\mathbf{1 8 6 7}$. By legend it is also linked to the Indian emperor Aśoka and is understood to be a living being inhabited by a powerful spirit. ${ }^{48}$ Each year during the New Year festival, the statue is moved to Vat Mai in Luang Phabang, where it is lustrated by the four head abbots of the town. As in the case of relic worship in Vientiane, the former king of Laos has been replaced by high-ranking politicians (the foreign minster and the provincial governor) who-after the four monks-also sprinkle water over the statue. Although this statue is mobile and subject to different ritual prostrations and offerings, the rituals carried out are also meant to renew the energies of the kingdom and, today, the nation-state of Laos. The ritual restructurings of the Buddhist palladium in Luang Phabang are marked by stronger disparities between past and present than in the case of the That Luang. However, a recent analysis of the New Year ceremonies in

Siam, and predecessor of Chulalongkorn, see C. Wilson, 'State and society in the reign of King Mongkut, 1851-1868: Thailand on the eve of modernization', PhD thesis, Cornell University, 1970.

${ }^{47}$ See the translation of the Luang Phabang chronicle by S. Phinit, Contribution à l'histoire du Royaume de Luang Prabang, École Française d'Extrême-Orient, Paris, 1987 , p. $5^{2}$.

${ }^{48}$ For the Phabang and another important statue called Pha Keo (to be discussed later), see R. Lingat, 'Le culte du Bouddha d'émeraude', Journal of the Siam Society, Vol. 27/1, 1934, pp. 9-38. There are also many popular Lao books on the statues to be found in the market in Vientiane. See C. Vannacid, phavad phrabang [History of the Phabang], Thavisay Publishing, Vientiane, 2005; and D. Luangphasi, tamnan phra keo moradok [Chronicle of the Pha Keo statue], Mitkhanpim Publishers, Vientiane, 2006. 
Luang Phabang also suggests that the cosmological background of the rites has only been marginally affected by current politics. ${ }^{49}$

\section{The ritual creation of living effigies of Buddhist kings}

Besides worshipping relics and statues that are already part of the Lao palladium, the creation of new statues of former kings in Vientiane has also been a prominent feature of Laos's recent cultural politics. ${ }^{50}$ I will here discuss the erection of the statue of King Fa Ngum (1316-1393) in 2003, and also refer in passing to the inauguration of the statue of King Anouvong (1 $767-1829)$ in 2010. Despite the different histories associated with these kings, certain aspects of the rites performed for them were very similar, specifically the rites of 'opening the eyes' (piti boek pranet). As I will elaborate further below, these rites make the statues into living effigies of deceased kings and imbue them with Buddhist dhamma. Moreover, in popular belief they house the spirit (phi) or consciousness (vinyan) of the king and therefore have protective qualities and energies that can be tapped into by current leaders through sponsoring their establishment and leading the rituals associated with them.

The casting of metal statues in mainland Southeast Asia was limited for centuries to images of the Buddha or certain deities deriving from the Hindu pantheon. In elaborate rituals these were activated

${ }^{49}$ For the procession, see Evans, 'Revolution and royal style', p. 201. The discontinuities of this replacement process are more obvious in Luang Prabang than in Vientiane because the last Buddhist king resided there, whereas Vientiane-which was an independent kingdom before the colonial era-has had no resident king since the nineteenth century. Consequently, memories of the king and the associated rituals are much more alive in Luang Phabang. The discontinuity is also visible in the worship of the Sridhamma Aśoka stūpa in Luang Prabang. Before the revolution the king meditated close by the stupa in order to load himself with Buddhist dhamma and identify with King Aśoka. See Reynolds, 'Ritual and social hierarchy', p. 82. Lao politicians do not meditate any more, but participate in the ritual worship of the relic. Platenkamp's analysis suggests, however, that these discrepancies only had a marginal impact upon the cosmology in Luang Phabang. See J. Platenkamp, 'Political change and ritual tenacity. The New Year's ritual of Luang Prabang (Laos)' in A. Iteanu (ed.), La cohérence en anthropologie sociale. Mélanges en hommage à Daniel de Coppet, Editions de la maison des sciences de l'homme, Paris, 2010, pp. 193-234. See also John Holt's (Spirits of the place, pp. 221-231) recent analysis of the interaction between Buddhism and spirit cults in the New Year celebrations.

${ }^{50}$ See O. Tappe, Geschichte, Nationsbildung und Legitimationspolitik in Laos. Untersuchungen zur laotischen nationalen Historiographie und Ikonographie, LIT, Muenster, 2008, pp. 242-253. 
and brought to life. With an increasing European presence-either as colonial powers or through general exposure to Western-style political organization-the first statues of former Buddhist kings were constructed in Thailand in around 19oo. Grant Evans, in an excellent article on 'statuemania' in Laos and Thailand, states that this development largely 'appears to be a phenomenon of the latter part of the twentieth century'. ${ }^{51}$ In Laos, the first statue of a king ever to be inaugurated was that of King Setthathilat (1534-1572) in 1957. It stands just in front of the That Luang relic shrine. After 1975, during the high phase of socialism, the creation of effigies of kings was unthinkable as they were considered 'imperialists' (cakkapad) of the 'feudalists system' (labob sakdina). In search for new sources of legitimation, however, we now see the creation of a cult of 'good' kings or 'national ancestors' (banphabulut) in Laos. ${ }^{52}$ In 2003, the Ministry of Information and Culture ordered the construction of a large statue of the Buddhist King Fa Ngoum, who is widely held to be the founder of 'Laos' in the fourteenth century through uniting smaller principalities to form the kingdom of Lane Xang in 1353 . $\mathrm{He}$ is also attributed with the introduction of Buddhism as a result of his exile in Cambodia. ${ }^{53}$ The ritual in January 2003 therefore also marked the 65 oth anniversary of the founding of the former kingdom. The second statue for King Anouvong was inaugurated in November 2010 on the esplanade of the Mekong River, celebrating the 45oth anniversary of Vientiane. In official Lao historiography, Anouvong is celebrated as the last king of Vientiane, who tried to defend Laos against Siam in the nineteenth century. His rebellion was defeated, Vientiane was burnt to the ground, and he was executed in Bangkok in 1829 .

The Fa Ngoum statue was inaugurated with a huge ritual extending over a period of several days, in which politicians, Buddhist monks, and thousands of spectators participated. It was perhaps the biggest

${ }^{51}$ G. Evans, 'Immobile memories: statues in Thailand and Laos' in S. Tanabe and C. Keyes (eds), Cultural crisis and social memory in Thailand and Laos, Routledge, London, 2002 , p. $15^{8 .}$

${ }^{52}$ See the recent study of this cult of kings and its significance for Lao nationalism: V. Grabowsky and O. Tappe, 'Important kings of Laos: translation and analysis of a Lao cartoon pamphlet', The Journal of Lao Studies, Vol. 2/1, 201 1, pp. 2-8.

${ }^{53}$ New historical evidence suggests otherwise. See M. Lorrillard, 'D'Angkor au Lån Xång: une révision des judgements', Aséanie, Vol. 7/1, 2001, pp. 19-33. However, the omnipresent references to King Fa Ngoum in conversations about the 'origin' of Lao Buddhism seems to confirm the success of these cultural politics that present the king as the 'spiritual father of the Lao nation'. 
procession Vientiane has seen for decades and most of my Lao friends were deeply enthusiastic about the ritual and sharply contrasted it with the organized (and, for them, very boring) socialist spectacle parades of the 1980 os. In a sort of historical re-enactment, the statue was paraded through the city to a park in central Vientiane where it was then donated 'to the people'. ${ }^{54}$ Moreover, the newspapers reported, two months before the official inauguration, the head of the statue was cast and blessed, with people donating gold and silver, and Brahmins performing the appropriate rites. The ritual programme was reported in detail in newspapers and shown on television. At first sight this might look like the politics of performance and the invention of a tradition engineered by the Ministry of Information and Culture. Indeed, the whole performance surrounding the erection of this statue and the others that followed were carefully planned and outlined in detail in a publication by the Ministry of Information and Culture. ${ }^{55}$ Nevertheless, the rites for the statue were in perfect harmony with traditional Buddhist ritual and cosmology: at 6am on 4 January 2003, a boek pranet ('opening of the eyes of the statue') ceremony was performed. Only then, when a cloth was removed from its eyes, was the statue completely unveiled. The boek praenet ritual was also performed for the Anouvong statue in 2010. What does this rite reveal to us and how are its powers conceptualized by worshippers?

The opening of the eye ceremony (Pāli: netra pinkama or akkhipuja) is widespread in Theravāda Buddhism. It is only through this mechanism that statues become living beings worthy of worship. The ritual was first mentioned by Buddhaghosa in the fifth century AD. He ascribes the festival to King Aśoka, who received a beautiful Buddha image and then ordered the celebration of the rite. ${ }^{56}$ The rite involves the allnight recitation of a multitude of texts known only to very experienced Buddhist monks. The chants, subsumed under the expression suat boek pranet ('chant of eye opening'), retell the story of the Buddha's enlightenment and elaborate on how he sat under the bodhi tree for the three watches of the night, developing an omniscient eye

\footnotetext{
${ }^{54}$ Ministry of Information and Culture, Phu nampha sathapana anacak lan sang ekaphap phanya fa ngum laenglathòlani khophòp 650 pi [The leader and builder of the united kingdom of Lan Xang. Phanya Fa Ngoum. $65^{\mathrm{o}^{\text {th }}}$ anniversary],Vientiane, 2002, p. 13. ${ }^{55}$ Ibid.

${ }^{56}$ R. Gombrich, 'Consecration of a Buddha image', Journal of Asian Studies, Vol. 26/1, 1966. p. 26.
} 
with which he could survey the whole cosmos. ${ }^{57}$ According to Donald Swearer, who has studied the ritual in the culturally very close region of northern Thailand, the rites 'sine qua non remained "enlivening" and "dhammasising" the image. The image is enlivened by opening its eyes; it is dhammacised by imbuing it with the ontological truth realized by the Buddha. ${ }^{58}$ Prior to this ritual, a statue is 'just' metal and only the central act of removing the wax or blindfold from the eyes transforms it. ${ }^{59}$ As a Lao friend of mine put it: 'Now the statue has virtue and dhamma.'

This kind of ritual of bringing statues to life can also be applied to statues that do not depict the Buddha. Heroes killed in battles and deceased kings who have become protectors of religion can be invoked, as in the case of Fa Ngoum and Anouvong. Francois Bizot's research has shown that besides the dhamma activated in these statues, there is an additional invocation of the spirit of the deceased person depicted through the image ${ }^{60}$ Bizot links this phenomenon to a preBuddhist culture that Paul Mus subsumed under the label 'cadastral cults' ${ }^{61}$ Sherry Ortner has described a very similar process in Nepal, where gods are invited to reside in statues; they are 'captured' through hospitality and serve as protective spirits, but also have to be regularly appeased and fed. ${ }^{62}$ Many Lao have told me that a spirit (phi) lives in the statue of Fa Ngoum and that of Anouvong. ${ }^{63}$ They become so-tosay living effigies that prolong the life of the king, comparable to those

${ }^{57}$ D. Swearer, Becoming the Buddha: the ritual of image consecration in Thailand, Princeton University Press, Princeton, 2004, pp. 164-172.

${ }^{58}$ Ibid, p. 211.

${ }^{59} \mathrm{~S}$. Tambiah, The Buddhist saints of the forest and the cult of amulets, Cambridge University Press, Cambridge, 1984, p. $25^{1}$.

${ }^{60}$ F. Bizot, 'La consécration des statues et le culte des morts', in François Bizot (ed.), Recherches nouvelles sur le Cambodge, École Française d'Extrême-Orient, Paris, 1994, pp. $125^{-127 .}$

${ }^{61} \mathrm{P}$. Mus, India seen from the East: Indian and indigenous cults in Champa, Monash University, Clayton, 1975 .

${ }^{62}$ S. Ortner, 'God's bodies, God's food. A symbolic analysis of a Sherpa ritual', in R. Willis (ed.), The interpretation of symbols, Wiley, New York, 1975, pp. 133169.

${ }^{63}$ The spirits living in these statues can embody themselves in human form through a medium. Close to the That Luang one finds a statue of King Setthathirath (15341572 ) that is also regularly worshipped by people. In 2005 , when I attended the yearly rite for this entity, the spirit was appeased with a buffalo sacrifice and took possession of female spirit mediums (nang tiam) who then answered the questions of the numerous devotees attending the rite. 
that were prominent in the royal funeral ceremonies of renaissance France. ${ }^{64}$

I think that the ritual enlivening of the statues plays a crucial role in creating a cult around them. Oliver Tappe has carried out interviews with worshippers of statues and has found out that belief in their saksit qualities is very much alive, even among younger people who grew up without kingship. ${ }^{65}$ Short interviews I conducted in 2011 regarding the worship of the Anouvong statue yielded very similar results. Some people reiterated the slogans disseminated by the Ministry of Information and Culture and described Anouvong as a national hero who had tried to defend Laos against Siamese hegemony and would now 'protect' Laos. Others, however, labelled the power of the statue as having dhamma, saksit, iddhi or lided ${ }^{66}$ The small stream of worshippers visiting the Anouvong statue prayed for better jobs, good health, for visas to enable work abroad, and other issues that preoccupied them in their everyday lives. One informant distinguished the worship of Fa Ngoum and Anouvong from that performed in front of a 'normal' Buddha statue. Worshipping with flowers, incense, and candles in front of a Buddha statue was for him bound up with being a good person, improving karma, and thinking of one's deceased relatives. For him, the worship of deceased kings was a practice that might increase his luck and enable him to manipulate his fortune.

The procession around the rite of enlivening the image also reveals an interesting detail. In a newspaper article with the heading 'King Fa Ngum reborn as Laos' spiritual hero', we read the following description:

Crowds gathered at the still-veiled Fa Ngoum statue to perform a morning religious ceremony. 57 senior monks from various temples in Vientiane participated [...] The ceremonies were made to appease the spirit of King Fa Ngoum as the guardian of the nation. [...] The afternoon procession was a re-enactment of the return of Fa Ngoum from the Khmer kingdom of Angkor Thom. Leading the procession was the Pha Bang statue, which the king brought with him from Angkor Thom along with Buddhism when

${ }^{64}$ See R. Giesey, 'The effigy as king alive' in R. Giesey, The royal funeral ceremony in Renaissance France, Librairie Droz, Paris, p. 145 ff. See also footnote 69 for further elaborations on the concept of a substitute body.

${ }^{65}$ Tappe, 'Geschichte, Nationsbildung', pp. $85^{-87}$.

${ }^{66}$ Lided translates from Sanskrit rddhi ('supernatural power') and teja ('radiant energy, transcendent power'). See M. Reinhorn, Dictionnaire Laotien-Français, Éditions du Centre national de la Recherche scientifique, Paris, 2001, p. 175o. Pāli iddhi also denotes 'supernatural power'. 
he united Lane Xang. The Pha Bang statue was followed by a procession of ancient manuscripts detailing the law and scriptures of Buddhism [... In emotional scenes, when the Pha Bang statue passed the crowds, they knelt down en mass in a sign of respect for the statue. ${ }^{67}$

Although I am not sure if the Phabang statue was connected to Fa Ngoum through ritual cords (say sin)—essential ritual paraphernalia for most Buddhist rites which signify a transfer-the presence of the Phabang suggests a ritual mechanism with which the statue of King Fa Ngoum is linked to an ancestral palladium. Tambiah explains that in the ritual act of giving life to a statue, another crucial element 'is the transmission of some portion of the virtues and powers of an already installed historic statue or a famous statue to the newly fashioned image'. ${ }^{68}$ As a result, the newly consecrated image was thereby initiated into the Lao palladium and is now considered to belong to the lineage of the presiding image.

In addition to linking the new statue of Fa Ngoum to the Phabang, there was also a performative re-enactment of the introduction of Buddhism to Laos. In Buddhist terms, the bringing of a statue imbued with the dhamma and a body of texts ('ancient manuscripts') is understood to invoke the Buddha's presence in two ways. The introduction of the rupakaya ('the form body' as statues or relics) and the dhammakaya ('body of teaching', that is, the scriptures of Buddhism) are 'the sine qua non for the establishment and maintenance of Buddhism as a historic religion'. ${ }^{69}$ This was also elaborated in a speech given by the minister of Information and Culture at the inauguration of the statue: 'He [Fa Ngoum] brought the Phabang, the sacred image of Buddha, and spread Buddhism in the country, teaching the entire people to live a right and honest life, to act righteously and avoid wrongdoing, to be generous to another [... ] We pray to King Fa

${ }^{67}$ Vientiane Times, 3 January 2003, p. 3 .

${ }^{68}$ Tambiah, The Buddhist saints, p. 253.

${ }^{69}$ See F. Reynolds, 'The several bodies of Buddha: reflections on a neglected aspect of the Theravāda tradition', History of Religions, Vol. 16/4, 1977, p. 378. Here one could also invoke Kantorowicz's study on the king's two bodies in medieval theology. Whereas the king's natural, mortal body (corpus naturale) would pass away with his death, he was also thought to have an enduring, supernatural (corpus mysticum) body that could not be destroyed. In this sense statues could be understood as a corpus mysticum. See E. Kantorowicz, The king's two bodies. A study in medieval political theology, Princeton University Press, Princeton, 1957. For an excellent elaboration of Kantorowicz's analysis, and an application of his concepts to India and Africa, see B. Schnepel, Twinned beings: kings and effigies in southern Sudan, east India and Renaissance France, Institute for Advanced Studies in Social Anthropology, Gothenburg, 1995. 
Ngoum to be with the Lao nation forever. ${ }^{70}$ Here, the introduction of Buddhism and the invocation of the presence of the spirit of a national hero go hand in hand.

\section{Conceptualizing the agency of relics and statues}

We have seen in two cases how the significance of relic cults and the power of animated statues have remained remarkably stable, despite the changed circumstances of their worship. Most ethnic Lao in my fieldsite in Vientiane and Khammouan province were enthralled by the ritual patronage of the That Luang relic and the recently erected statues. Prosperity (caloen) and development (pathana) were the terms that were regularly mentioned by my informants in relation to the That Luang. Whereas peasants from my second, rural fieldsite in the south of Laos understood this in more agricultural terms (thus making prosperity a larger category for the 'whole nation'), urban citizens of Vientiane often referred to the economy and the process of developing the country (pathana pathed). The statues were also given the qualities of a living being: they are imbued with dhamma and house a spirit, but also have supernatural powers (saksit, lided, iddhi) that can be of help to worshippers.

Thus, despite the discontinuities provoked by the abolishment of kingship, the rituals also function without the institutional framework of Buddhist kingship, as the continuity of the cosmological underpinnings allow for adaptations. What might aid this process of cooption by the current Lao government is the fact that relics and statues are understood as having an agency of their own, which can be appropriated outside the framework of Buddhist kingship. If our only focus is on the king as a charismatic figure in the Weberian sense, I think we run the risk of neglecting the role played by objects such as statues and relics. Although from early on, research on Christianity in late antiquity and the Middle Ages has explored the 'potentia' of the relics of saints, ${ }^{71}$ studies of religion have been criticized recently for their heavy focus on human agency and intentionality, neglecting

${ }^{70}$ Vientiane Times, 3 January 2003, p. 4 .

${ }^{71}$ See the seminal study of $\mathrm{P}$. Brown, The cult of the saints. Its rise and function in Latin Christianity, University of Chicago Press, Chicago, 1981, p. 106ff. Brown also paved the way for research on relics in Buddhism. However, one also has to point to the limitations of such wide-ranging comparisons. See J. Strong, 'Buddhist relics in comparative perspective. Beyond the parallels', in Germano and Trainor (eds), Embodying dharma, p. 43 . 
material aspects. This is especially applicable to world-renouncing religions such as Buddhism, ${ }^{72}$ but moreover is an 'ontological problem of reference in representing the divine'. ${ }^{73} \mathrm{I}$ think that in order to understand this continuity we must take the 'living' qualities of relics and statues seriously, and focus on their materiality, their history, and their ontological qualities linked to fertility, prosperity, and fortune.

One could explain this endurance by referring to the narratives that have evolved around relics and statues, and by representing them as objects that have agency. As I mentioned before, chronicles in premodern Theravāda Southeast Asia often focused on the travels of relics and statues. Thus the continuity of these narratives and their historicity can be seen to confer supernatural qualities and agency on them. Tambiah seems to follow this line of interpretation when he states that 'the Buddha statue as a palladium is a product of the circumstances of its making and the authenticity given by its makers, sponsors, patrons. In this sense history is embedded and objectified in it. This very objectified presence in turn radiates upon and influences human actors and events. ${ }^{.74}$

But could we also employ another perspective that conceptualizes the objects and their agency beyond their historicity? Taking Tambiah's second sentence more literally, I think here it is crucial to see these effigies not only as representing kings or history, but also as relics that stand for the dhamma, but employ a different perspective, as advocated, for example, by Henare, Holbraad, and Wastell regarding the agency and ontological status of objects. ${ }^{75}$ Here, it is not exclusively the human subject that moulds the material world through its agency, nor projects meaning into the object, thereby making it into a representation or symbol. Instead, there

\footnotetext{
${ }^{72}$ See, for example, P. Manning and A. Meneley, 'Material objects in cosmological worlds: an introduction', Ethnos, Vol. 73/3, 2008, p. 289-9o.

${ }^{73}$ R. Sharff, 'On the allure of Buddhist relics', Representations, Vol. 66/1, 1999, p. 81. For a theoretical elaboration of the problem of reference, trace, and representation of the immaterial, see P. Ladwig, 'Ontology, materiality and spectral traces. Methodological thoughts on studying Lao Buddhist festivals for ghosts and ancestral spirits', Anthropological Theory, Vol. 12/4, 201 2, p. 431.

${ }^{74}$ Tambiah, 'Famous Buddha images', p. 18, my emphasis.

${ }^{75}$ See A. Henare, M. Holbraad and S. Wastell (eds), Thinking through things: theorising artefacts ethnographically, Routledge, London, 2007. For a critical, in-depth assessment of the ontological turn in anthropology, see the Manchester round table discussion in anthropology: 'Ontology is just another word for culture', Critique of Anthropology, Vol. 30/2, pp. $15^{2-200 .}$
} 
are efforts to restore the role of objects and non-human entities beyond dead matter, fetishism or representations and symbols, leaving space for their agency and their powers. Henare, Holbraad and Wastell, referring to the link between ontology and materiality, argue that 'rather than accepting that meanings are fundamentally separate from their material manifestations (signifier vs. signified, word vs. referent, etc.) the aim is to explore the consequences of an apparently counter-intuitive possibility: that things might be treated as sui generis meanings' ${ }^{76}$ Moreover, they state that we should 'take "things" encountered in the field as they present themselves, rather than immediately assuming that they signify, represent or stand for something else'.77 Justin McDaniel has applied similar theories to 'art objects' in Thailand. ${ }^{78}$ As we have seen in the case of relics and statues, they actively emanate through their qualities as saksit or lided and have agency - they do not only mirror or represent. The relic of the That Luang is said to have khwan (soul substance). Taking the emic ontological qualities of relics and statues seriously, in my opinion, opens up a methodological framework for understanding their continuing efficacy, despite the disappearance of kingship. If they only represent, signify or stand for protection, fertility, and growth, we miss their crucial role in perpetuating these qualities in a new context. Taking the emic qualities of the statues seriously can also explain the failure of Lao revolutionary leaders such as Kaysone Phomvihane (1920-1992) to create a cult around the statues, as they were never ritually activated. Here ritualization, as 'a strategy for the construction of certain types of power relationships effective within particular social organizations' ${ }^{79}$ remained largely unsuccessful, while in combination with living entities such as relics and statues, it is highly effective. ${ }^{80}$

${ }^{76}$ Henare et al., Thinking through things, p. 3 .

${ }^{77}$ Ibid. p. 2. For further theoretical elaboration of the implications of theories of materiality and the status of objects see, for example, W. Keane, 'Subject and object' in C. Tilley, W. Keane, S. Küchler, M. Rowlands and P. Spyer (eds), Handbook of material culture, Sage Press, New York, 2006, pp. 197-202. For the point that objects can embody complex intentionalities and mediate social agency, see A. Gell, Art and agency. An anthropological theory, Clarendon Press, Oxford, 1998.

${ }^{78}$ Focusing 'on the agency of the things themselves', he gives several examples of how specific 'objects' (relics, statues, murals, and other images) can be conceptualized beyond art history and iconography. See J. McDaniel, The lovelorn ghost and the magical monk. Practicing Buddhism in modern Thailand, Columbia University Press, New York, 2011, p. 164.

${ }^{79}$ C. Bell, Ritual theory, ritual practice, Oxford University Press, New York, p. 197.

${ }^{80}$ Obviously, there are various possible explanations for this. These might be related to the missing ancestor lineages in the Lao kinship system and its cosmology, and 
However, it is not possible to completely disconnect the palladium, its material manifestations, and the rulers who claim legitimacy with its help. Relics and statues can also become sites for the contestation of legitimacy. In Theravāda Buddhism it is not only the possession of relics or statues that is crucial-the leader must also have the power and the integrity to handle them. Wyatt states with regard to premodern Thailand:

Relics are worth troubling over, for their presence confers boons upon those who venerate them, and they connect those people with a religion wider in space and time. Relics are so powerful, however, that they cannot be treated lightly, and they must be handled by people who themselves have a considerable fund of positive moral power. If they are handled by unworthy people, particularly unworthy rulers, then all sorts of calamities could be visited upon the country. ${ }^{81}$

Transposing this to the current period might imply, for example, that either the right of rulers to own them might be contested or that the authenticity of relics and statues is questioned. Grant Evans, for example, reports rumours that the sacred Phabang statue is fake and just a copy. ${ }^{82}$ I myself have heard endless variations of similar stories in Luang Phabang and Vientiane. They usually relate that the original Phabang statue was captured by the revolutionary forces in 1976 and locked up in a secret place in Vientiane. For Evans, these rumours can be read as a political comment on the illegitimacy of the current Lao government. ${ }^{83}$ However, although most Lao from Vientiane are aware of the absence of the king, most do not regard the statues and relics that are objects of state rituals as fake.

The disappearance of certain statues that were once housed in Lao temples and palaces still fuels the religious imagination and speaks for the belief in their agency. The quarrels over the Pha Keothe emerald Buddha today housed in Bangkok's Grand Palace and situated within Wat Phra Keo-are probably the best example of

the lack of charisma of the depicted figure. See Evans, 'The politics of ritual and remembrance', p. 24f. However, I think this is also grounded in the fact that these statues were produced in North Korea and were never ritually brought to life. Some Lao friends mentioned that these statues are just for 'remembering the revolution' and attributed no other qualities to them.

${ }^{81}$ D. Wyatt, 'Relics, oaths and politics in thirteenth-century Siam', Journal of Southeast Asian Studies, Vol. 32/1, 2001, p. 31.

${ }^{82}$ Evans, 'Immobile memories', p. 195.

${ }^{83}$ However, this could also be read the other way around: the new communist power holders took the Phabang to the revolutionary capital Vientiane in order to secure its power and have control over it. 
this: the Pha Keo has moved through the region for centuries and was positioned in different religious and political centres. It was taken away from Vientiane in 1779 during the suppression of a revolt, and then transferred to Thonburi and finally Bangkok. ${ }^{84}$ Today it serves as the palladium of Thailand. Lao people regularly complain about the 'theft' of the statue. During the floods in Thailand in October and November 201 1, a copied leaflet appeared in Vientiane that presented a story describing the 'theft' of the statue from Laos. It elaborated on a prediction made at the time of the removal of the Pha Keo from Laos: flooding, political quarrels, and social unrest would be visited upon the country that appropriated it. The leaflet was alluding to the calamities that had been experienced in Thailand during recent years. This, together with the heavy flooding, was seen as a fulfilment of the prediction and indirectly claimed that the Pha Keo actually belongs to Laos.

Taking a more regional, comparative perspective, we find in Burma a case of a more open contestation over relic cults employed by the state. Juliane Schober reports on the tour of the Chinese tooth relic through Burma. Subject to excessive media coverage on Burmese state television, the authenticity of the relic was a subject of much discussion, according to Schober. Her informants told her that the Chinese monks accompanying the relic were 'fake monks', working as spies for the government. ${ }^{85}$ Sara Davis's account of Chiang Tung in northern Burma is also interesting in this regard. There the Burmese state sponsors the erection of statues and relic shrines in order to promote Buddhism in the ethnically heterogeneous region. Davis recorded rumours about statues that, according to her Burmese informants, are said to contain fake relics and are produced with a Burmese form of black magic. People passing by the statues try not to look into their eyes, as they fear being manipulated by them. Despite the fact that the relics are considered fake, they are still deemed to be efficacious-not in terms of fertility and prosperity, but instead moral corruption and sickness. ${ }^{86}$

${ }^{84}$ See K. S. Narula, Voyage of the Emerald Buddha, Oxford University Press, Kuala Lumpur, 1994; and C. Notton, The chronicle of the Emerald Buddha, Bangkok Times Press, Bangkok, 1933 .

${ }^{85} \mathrm{~J}$. Schober, 'Buddhist just rule and Burmese national culture: state patronage of the Chinese tooth relic in Myanmar', History of Religions, Vol. 36/3, 1997, pp. $218-243$.

${ }^{86}$ S. Davis, Song and silence. Ethnic revival on China's southwest borders, Columbia University Press, New York, 2005, pp. 163-166. 


\section{Conclusion}

In an article on the post-colonial fate of Buddhist kingship in Sri Lanka and Burma, Edmund Leach states: 'Fantasy apart, there is in fact very little in the present-day political organization of either Burma or Ceylon which derives directly from the traditional forms of pre-colonial centralized Kingship. ${ }^{87}$ Although Leach's analysis is undoubtedly right regarding the institutions and figures of kingship, the material manifestations of kingship in Laos and some other Theravāda Buddhist countries point to the continuing relevance of models of kingship and Buddhist statecraft. By acting as patrons of relics shrines such as the That Luang, the current Lao government represents itself as a protector of Buddhism, and by erecting new statues, it maps the (now nationalized) territory with living monuments and a sacred topography. Instead of a king making a donation of a relic, temple or Buddha statue, we now have the representatives of the modern party state giving statues and parks to 'the people'.

With reference to theories of materiality and the ontological status of relics and statues, I have argued that their active qualities are crucial for understanding the continued legacy of Buddhist statecraft. As these statues radiate, emanate, and live, they are understood by worshippers to give protection and are sources of agricultural and economic prosperity. Lao notions such as caloen and patthana still derive their power from the belief in palladia, and their effects can also be translated into modern idioms of development and prosperity. Current rulers can harness these qualities by controlling the rituals surrounding the palladium. Moreover, they can follow the example of Buddhist kings and create new sources of 'objectified charisma' and thereby create new places of worship, make sacred national heroes of the past, and map the territory of the nation-state.

Perhaps what Leach, in the quote above, called 'fantasy' would today be understood as 'imaginary'. Taking this perspective, the situation in Laos has some parallels to other Theravāda Buddhist countries in which kingship has disappeared, while the imaginary of kingship and its material manifestations are still crucial for gaining political legitimacy. Here, 'traditional' and allegedly 'modern' forms of power intermingle and continue to blur the lines of the secular, the religious, and the political. One the one hand, this process is

${ }^{87}$ E. Leach, 'Buddhism in the post-colonial political order in Burma and Ceylon', Daedalus, Vol. 102/1, 1973, p. 4o. 
negotiated in the political institutions of the state that has recognized the usefulness of pragmatically integrating Buddhism, its rituals, and symbolisms as long as they are subordinated to the state's power. On the other hand, this criss-crossing of 'secular politics' with 'religion' would be impossible without the continuity of Buddhist notions of power associated with relics and statues. ${ }^{88}$ This does not transcend the discontinuities and historical ruptures that have occurred in Laos, but shows that Buddhist kingship and statecraft continue to be of importance in a seemingly secular socialist party state that has no king.

\footnotetext{
${ }^{88}$ The secular and religious are now widely recognized as having specific historical genealogies. See T. Asad, Formations of the secular: Christianity, Islam, modernity, Stanford University Press, Stanford, 2003. For a tentative application of some of these insights to the case of Lao Buddhism, see P. Ladwig, 'The genesis and demarcation of the religious field: monasteries, state schools, and the secular sphere in Lao Buddhism (1893-1975)', Sojourn. Journal of Social Issues in Southeast Asia, Vol. 26/2, 2011 , pp. 21 off.
} 